\begin{tabular}{c} 
Volume and Issues Obtainable at Center for Sustainability Research and Consultancy \\
Journal of Accounting and Finance in Emerging Economies \\
ISSN: 2519-0318 ISSN (E) 2518-8488 \\
Volume 5: Issue 1 June 2019 \\
JSRᄃ \\
Journal homepage: www.publishing.globalcsrc.org/jafee \\
\hline
\end{tabular}

\title{
Impact of Corporate Social Responsibility Awards on Share Prices
}

\author{
${ }^{1}$ Zeeshan Mahmood, ${ }^{2}$ Javed Iqbal, ${ }^{3}$ Waris Ali, ${ }^{4}$ Muhammad Aamir \\ ${ }^{1}$ Department of Commerce, Bahauddin Zakariya University, Multan, Pakistan. \\ Email: zeeshanmahmood@bzu.edu.pk \\ ${ }^{2}$ Institute of Management Sciences, Bahauddin Zakariya University, Multan, Pakistan. \\ Eamil: javediqbal@bzu.edu.pk \\ ${ }^{3}$ Department of Business Aministration, University of Sahiwal, Pakistan. \\ Email: waris.ali@bzu.edu.pk \\ ${ }^{4}$ Department of Commerce, Bahauddin Zakariya University, Multan, Pakistan
}

\begin{tabular}{l}
\hline ARTICLE DETAILS \\
\hline History \\
Revised format: May 2019 \\
Available Online: June 2019 \\
\\
\hline Keywords \\
Corporate Social \\
Responsibility (CSR), CSR \\
Awards, Abnormal Return \\
(AR), Cumulative Abnormal \\
Return (CAR), Pakistan Stock \\
Exchange
\end{tabular}

JEL Classification:

G30, G34, O24

\begin{abstract}
This paper provides empirical evidence to evaluate the business case of corporate social responsibility. In contrast to former studies, we choose to examine the relationship between corporate social responsibility awards and share prices. We examined this relationship in the contextual setting of Pakistan, where several award schemes are operating to reward CSR performance. An event study methodology was adopted to investigate the impact of award announcement on the abnormal return of TOP 100 companies listed on the Pakistan Stock Exchange. A daily price for each company was collected during the estimation window of 120 days before the event window and an event window of 3 days $[-1,0,1]$. Our analysis shows that the overall announcement of CSR awards has an insignificant impact on share price.
\end{abstract}

(C) 2019 Under a Creative Commons Attribution-NonCommercial-

ShareAlike 4.0

Corresponding author's email address: zeeshanmahmood@bzu.edu.pk

Recommended citation: Mahmood, Z., Iqbal, J. Ali, W. and Aamir, M. (2019) Impact of Corporate Social Responsibility Awards on Share Prices. Journal of Accounting and Finance in Emerging Economies, 5 (1), 141-154

DOI: $10.26710 /$ jafee.v5i1.682

\section{Introduction}

Corporate Social Responsibility (CSR) concept is getting attention while making business decisions and policy debates in Pakistan. Although there are many challenges to measure the impact of corporate social responsibility, corporations' investments in CSR activities has been growing significantly as a strategy for business and have importance for value creation (McWilliams, Siegel, \& Wright, 2006). The stock market provides a place where the stakeholders can interlink themselves with many firms and form new relationships with customers and increase their competitiveness in the market (Zanotti, 2012). Currently there are number of CSR rating agencies that are contending based on diversity of ratings methodologies. Rating agencies measure firms on their Corporate Social Performance (CSP) and issues ratings. CSR rating agencies have a transnational impact, among others, on the leading firms and their stakeholders (Scalet \& Kelly, 2010). 
The main objective of this research is to study the market reaction to CSR awards. The market studied is Pakistani companies who got CSR awards by National Forum for Environment and Health (NFEH). The major implication is to find the relationship between awards announcements and stock prices. For the purpose of this research, event study methodology was used. It addresses the impact of CSR awards on stock prices, which is missing from both the event studies and CSR literature. This research is mainly concerned with short term investor reactions, around announcement dates of CSR awards.

\section{Literature Review}

Over the last 25 years, many researchers worked on the concept of Corporate Social Responsibility (hereafter CSR), but little focus has been given to understand that why corporation always act in socially responsible ways (Campbell, 2007). CSR has been shown to increase the corporation's profitability ratio (Orlitzky, Schmidt, \& Rynes, 2003). Asymmetric information results in uncertain outcomes (McWilliams et al., 2006). There are two types of CSR motives extrinsic and intrinsic. Extrinsic motives are financial motives which can be achieved through CSR activities. Intrinsic motives are nonfinancial motives that observe Corporate Social Responsibility independent from financial benefits.

Beneficial impacts of CSR activities are; Company image, status \& reputation, enhanced employee's motivation and retention, Cost savings, CSR activities increases revenue and market share of firms and CSR activities reduce risk. While costs of CSR can be related to CSR engagements. CSR cost may be one-time cost or might be continuous cost. One time cost which firms incur once during the business and get benefit for multiple years such as donations, installations and other related investments cost. Continuous cost which firms bears or paid after regular interval or during a specific period, such as fees, cost of materials, promotion of corporate social responsibility activities, marketing operations, licenses, patents, copy rights. Other possible cost of CSR engagements which arises from the active CSR activities is social media, print media, electronic media and nongovernments organization, which leads to higher exposure.

Existing studies on CSR focus on the non-financial (marketing-related) outcomes, such as social sponsorship (Simmons \& Becker-Olsen, 2006) cause-related marketing (Barone, Miyazaki, \& Taylor, 2000; Varadarajan \& Menon, 1988) collaborating with consumers related to Corporate Social Responsibility issues (Caruana \& Crane, 2008) environmental marketing (Crouch, 2006) corporate repute (Berens, Van Riel, \& Van Bruggen, 2005). CSR issues have also been examined by the researchers from the stakeholder perception, that has been focused on stakeholders communications (Basu \& Palazzo, 2008), the effect of shareholder relationships on corporation sustainability (Choi \& Wang, 2009). Corporate Social Responsibility attentiveness between investors and its connection with corporate social and financial performance, investment in securities, and loyalty of employees (Sen, Bhattacharya, \& Korschun, 2006). Instead of variability and complications of the CSR related approaches; there are some basics and conventional theories on the Corporate Social Responsibility. The theories which are related to CSR are: Efficient Market Hypotheses, legitimacy theory, stakeholder's theory, signaling theory and resource dependence theory.

Many researchers, in recent years, have made attempt to investigate the financial outcomes of CSR. The study of Bass and Steidlmeier (1999) is one of the best and first actions in this field. The association between CSR and financial performance has been considered very important in the field of business and management, and investors are also in this area of study (Weber, 2008). The relationship between corporate social responsibility and firm's financial performance may be positive, neutral or negative. In the light of findings in the study of Ullmann (1985), Vance (1975) established that there was a negative relationship among CSR and financial performance of firms, which disproved the earlier research conducted by Moskowitz (1972). Makni, Francoeur, and Bellavance (2009) detected a negative effect of CSR on the performance of stock market, which shows the similar findings as also did (Baird, Geylani, \& Roberts, 2012).

CSR actions are regarded as strategic goal of firms for achieving competitive advantage, which would result to produce long term profits. This indicates the role of CSR in firms' stock returns. Rating agencies evaluate companies based on Corporate Social Performance (CSP) and some rating agencies such as Vigeo, based on their performance of management from a CSR point of view. This development confirms that the interest of financial world for such rating agencies and would yield some standardization of the different methodologies. So, it would 
be very interesting to know that if these social ratings indicate a market reaction and investors' behaviors modification. The study of Arya and Zhang (2009) that looked for institutional reforms and investor behaviors and reactions to CSR announcements in the emerging economies. Chollet and Cellier (2011) studied that the effect of CSR rating announcement on the prices of stock. While the study used CSR rating of firms, it is contended that those firms which had poor social and environmental ratings can damage a company's reputations and performance. Moreover, corporate social ratings are hardly evaluated and have been criticized due to the lack of transparency in rating of different rating agencies using different methodology

Brammer, Brooks, and Pavelin (2009) explored that there is a link among corporate social performance and share price return and shown that firms having high CSR scores have decreasing stock return, whereas the companies with the lowest score on CSR outperformed and have abnormal returns. Gupta (2006) in his study investigated the Impact of earnings Announcements on share prices and he researched on market reaction related to earning announcements in the Indian market and tested that whether these stock prices possess any information content. In his study he found that the Average Abnormal Return (AAR) is larger and greater than zero on the day of announcement and AAR is less than zero for bad news. Higher earnings announcement than the expected by investors leads to a rise in the stock returns on the days before the announcements and stock return decreases after news has been announced (Kong \& Taghavi, 2006). Patell and Wolfson (1984) examined earnings and dividend releases effects on stock prices and they found that stock prices reaction is greater than in response to earnings announcements than dividends announcements.

Maina (2009) explored stock prices and market reactions about annually earnings announcements for the companies that are listed at the NSE and he found that the average abnormal returns and average abnormal volume are significantly greater than zero as compared with the nonevent period. Onyang (2004) discovered through the sample of 48 companied that are listed at the NSE for the period $(1998-2003)$ established that announcements related to any good news or bad news contain important, material and relevant information to investors which are fully impounded by the stock market preceding the date of announcement.

In the CSR studies an event study methodology had been used to test the impact of these CSR announcements and events on the financial performance. According to some researchers that CSR events and announcements only yield benefit for short period of time around the announcements' dates. There are many reasons of yielding different results. It could be due to multiple time periods used in their studies and taking sample of different types of firms from different sectors. Some studies found positive impact of CSR rating announcements, some found negative and other found no relationship. So, to avoid this problem of inconsistent results by using CSR ranking which have issued by the different CSR rating agencies and different methodology has been used assess the firms and to give scores. In this study CSR awards announcements, which are awarded by many organizations such as NFEH instead of using CSR ranking or CSR rating announcements. Instead of using subjective based CSR rating announcements, the study will use the actual announcements of CSR awards as a proxy for social performance. Secondly, rather than using accounting-based ratios and formulas which gives the variation of results, this study will measure financial performance of firms by means of stock return.

According to signaling theory, the announcements of CSR awards send important signals to the investors. If CSR Awards announcements is considered positive signal to the investors, then market quickly responds and if CSR awards announcements is considered a negative signal by investors then market will react negatively. So, the investor respond to the CSR awards announcements is difficult for prediction, the idea behind our study is that to investigate whether CSR awards have positive or negative impact on the stock return of all those firms who win CSR awards. So, we propose two basics hypothesis to test whether announcements of CSR awards have positive impact on stock return or negative impact on stock return around the announcement's dates for short period of time;

Hypothesis 1:

Ho: The announcement of CSR Awards induces a positive significant impact on the share prices of event firms.

Hypothesis 2:

H1: The announcement of CSR Awards induces a negative significant impact on the share prices of event firms. 


\section{Methodology}

We took companies from two award schemes from National Forum for Environment and Health (NFEH) for the year 2010 to 2015. National Forum for Environment and Health (NFEH) introduces the Annual environment excellence Award (AEEA) to identify best practices and excellence in Corporate Social Responsibility (CSR) in sustainable business. Its intentions to display case innovative corporate initiatives which are portion of a comprehensive sustainable strategy and discourse the utmost pressing environmental and social challenges. The judges are nominated by an independent jury who appraise the participants on their performance in the past and their ongoing projects in the CSR realm. Another Award which is awarded by National forum for environment and health (NFEH) is CSR business excellence awards. The purpose of introducing this award is to investigate the best Corporate Social responsibility business practices according to the international standards and norms and to enhance those firms which are engaged in the CSR activities.

There are two variables in the proposed hypothesis one is dependent and other is independent variables, stock prices of firms are dependent of announcements of CSR awards. So, CSR awards represents as independent variables and stock prices represents as a dependent variable. Following framework explains the structure these two variables.

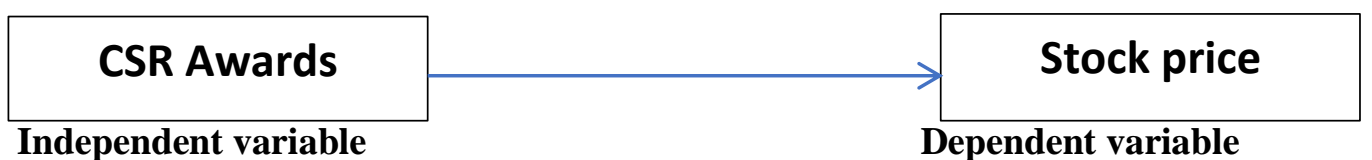

Event study methodology is used to test market reaction towards unexpected events such as announcement of CSR awards, dividend announcements, on the stock prices. According to McWilliams, Siegel, \& Teoh, (1999) the event study was established to measure the impact of unexpected event on the stock return that shows the market reaction to the announcements of events as average change in the share prices of firms who are engaged in the CSR activities.

Event study methodology has three assumptions which are as follows

- The stock market should be efficient market which reflects the all available information as past information, public information and private information which means fully and quickly reflect the al type's corporate announcements.

- During the period of analysis like estimation window and event window which is main focus point of research, event should be the only event which has significant impact on the changes in share price. Even if ant other event happened micro or macro, it would not have any impact on the stock prices changes. If there is any other factor which influenced the stock price then accurate result might not be generated around the announcements dates.

- Finally, the impact of announcements in response to the market reaction should be measured in terms of abnormal rate of return (ARR) during the event window.

Following are the basic steps which have been followed in this event study analysis, recommended by MacKinlay.

- Event of interest

- Date of event

- Define the interval of time for event window.

- To set estimation window.

- Sample selection

- Selection of model

- Collection of data. Downloaded share prices of firms who are engaged in CSR activities and winner of CSR award and also downloaded the data of market index i.e. KSE 100 index. 
- To calculate the daily stock price return and return of market index.

- To estimate the Alpha and Beta, we used the data of estimation period.

- To calculate Alpha and beta which are two basic parameters, are used to calculate the daily expected return.

- Calculation of daily abnormal return (AR) and generate the cumulative abnormal return (CAR) and also average abnormal return (AAR).

- Apply the significance test

The most important things when conducting an event study methodology to select the event of interest which mean what types of event are using in the study. The initial step of event study is to identify event types.

Following types of events can be analyzed in this study for example;

- If there are financial crises

- Announcements of earning

- Split of stock

- Incurring of micro and macro-economic factors

- Dividend announcements

- Publications of financial reports of companies

- Announcements of CSR awards

But in this study our event of interest is the announcements of CSR awards to test that what are impact of stock return of firms who are engaged in CSR activities and wins the awards. Our concern is not to discuss the evaluation criteria of organization who are awarded CSR awards; how these organization gives CSR scores to every company, we only test what are the effects of CSR awards on share prices of award winner firms, so our event interest is the announcements of CSR awards.

According to MacKinaly (1997), the selection of event date is most important for the selection of estimation period. There are multiple time periods for different awards in multiple years and in our study event dates is date of announcements of CSR awards.

A huge literature is available on the event study in finance, in which reaction of stock market has been analyzed towards the announcements of corporate news. That literature investigated the different types of announcements related to corporations such as dividend announcements, stock splits, and issue of equity (Kothari \& Warner, 2007; MacKinlay, 1997). This study uses three-day interval [-1, 0, 1], for event window period because event study provides more accurate result after the event for short period. There is greater uncertainty to check the real impact on the share price in the long-term period due to effect of many other factors which affects after announcements.

Next step is to define the estimation window to found that what reaction of market without the event window. Estimation window might be before the prior event period, but estimation window may be established after the event window and in some cases, it can be during the event window. The basic goal behind the establishing estimation window is to estimate the financial performance of firms unbiased. In this study, the estimation window is chosen 120 days before the event window which is proposed by MacKinlay (1997) while dealing with the daily share price data and using market model. To get the accurate results, period of event window is not included in the estimation period to ensure that event itself have no impact to estimate the normal performance of parameter Alpha and Beta. So, the estimation period ranges from 121 days prior to event window which covers the one day before the event window. Finally, total time period used in this study is 123 days which includes 120 days of estimation window, 3 days event window which indicate the 1 day before the announcements date, day 0 is the day of announcements and 1 day after the announcements.

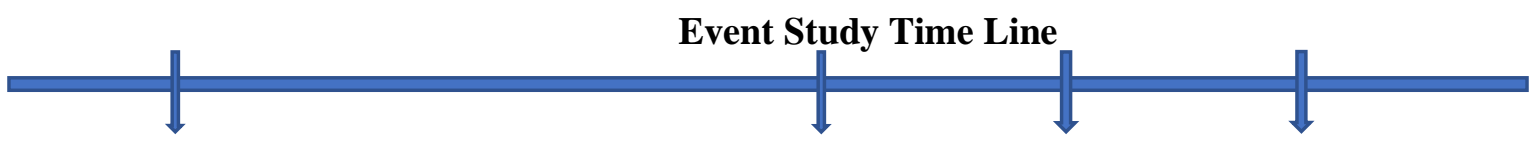




$$
\mathrm{t}=-120 \quad \mathrm{t}=-1 \quad \mathrm{t}=0 \quad \mathrm{t}=1
$$

Time period between $t=-1$ and $t=1$ shows the event window and time period between $t=-120$ and $t=-1$ show the estimation window.

\section{Findings and Discussion}

To meet the desired objectives of research share prices of firms has been collected which are listed on the Pakistan Stock Exchange (PSX) which are the winner of CSR awards, name of the winner companies and all other detail has been provided in the appendix. This study analyzes the effect of CSR awards announcement on the stock return of firms with the event window period of 3 days. We calculated the actual return, expected return, abnormal return, average abnormal return and cumulative abnormal return. Only charts have been provided about results of different CSR awards in this section. A t-test has been applied to test whether changes are significant or not. A $95 \%$ confidence interval has been used to generate result.

\subsection{Results of Annual Environmental Excellence Award (AEEA)}

In this section result about AEEA has been discussed for the year 2010 to 2015 . We have only presented here chart which shows results about expected return, abnormal return and cumulative abnormal return.

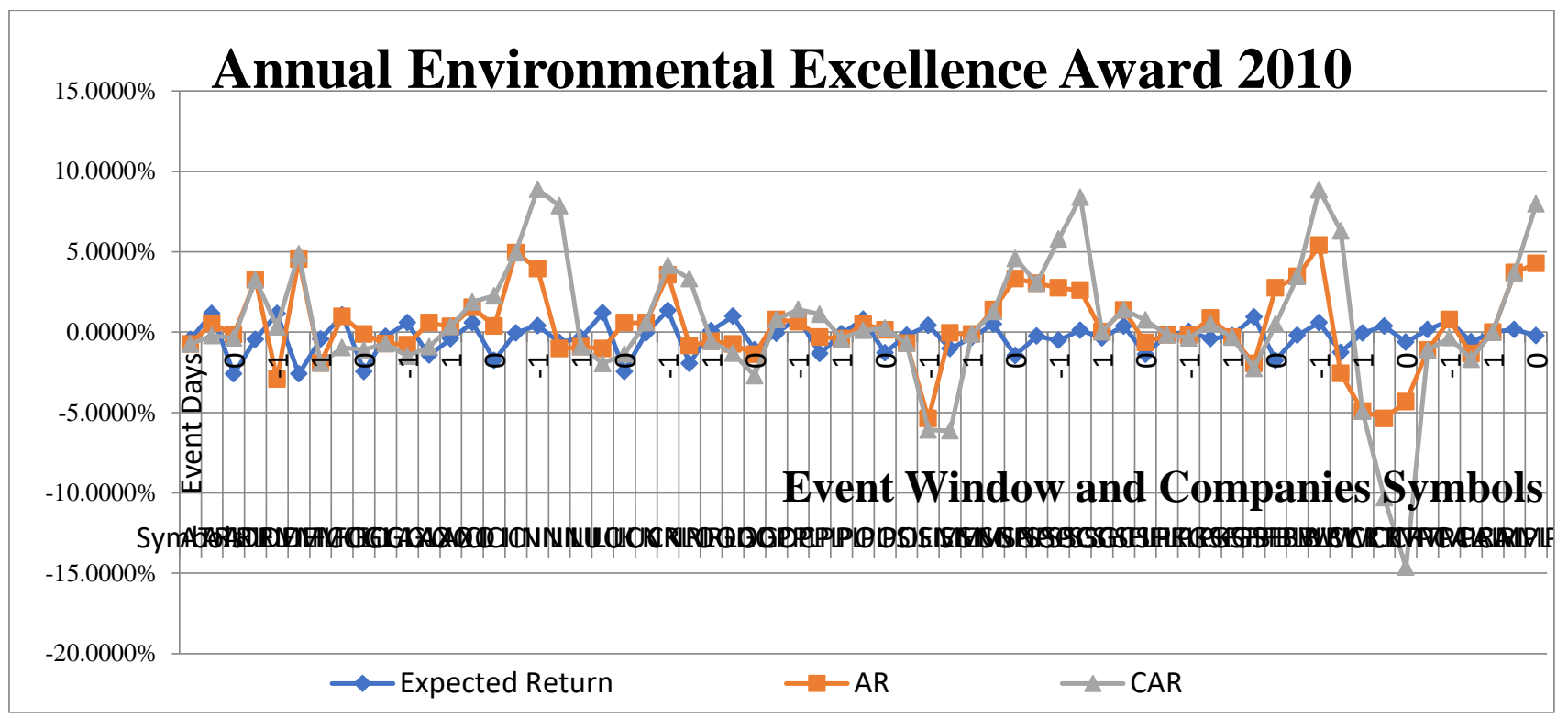

Figure \# 1: Annual Environmental Excellence Award 2010

The above chart depicts the expected return, abnormal return and cumulative abnormal return of the events firms around the event window i.e. -1 and 1 days for year 2010. It shows that mostly companies have insignificant impact of CSR Award announcement on the share prices. Out of 57 companies who have won CSR awards in the year 2010, only three companies have significant impact which includes INIL, NRL and SIEM. INIL has significant impact before the announcements day (4.94\%) and on the day of announcement (3.94\%) but insignificant after the announcement day (-1.03\%). NRL has significant impact on the day of announcements (3.56\%) only, before $(0.57 \%)$ and after $(-0.82 \%)$ the announcements have insignificant impact. SIEM has significant impact on the day of announcements $(-5.37 \%)$, before $(-0.7 \%)$ and after $(-0.06 \%)$ the announcements have insignificant impact. 


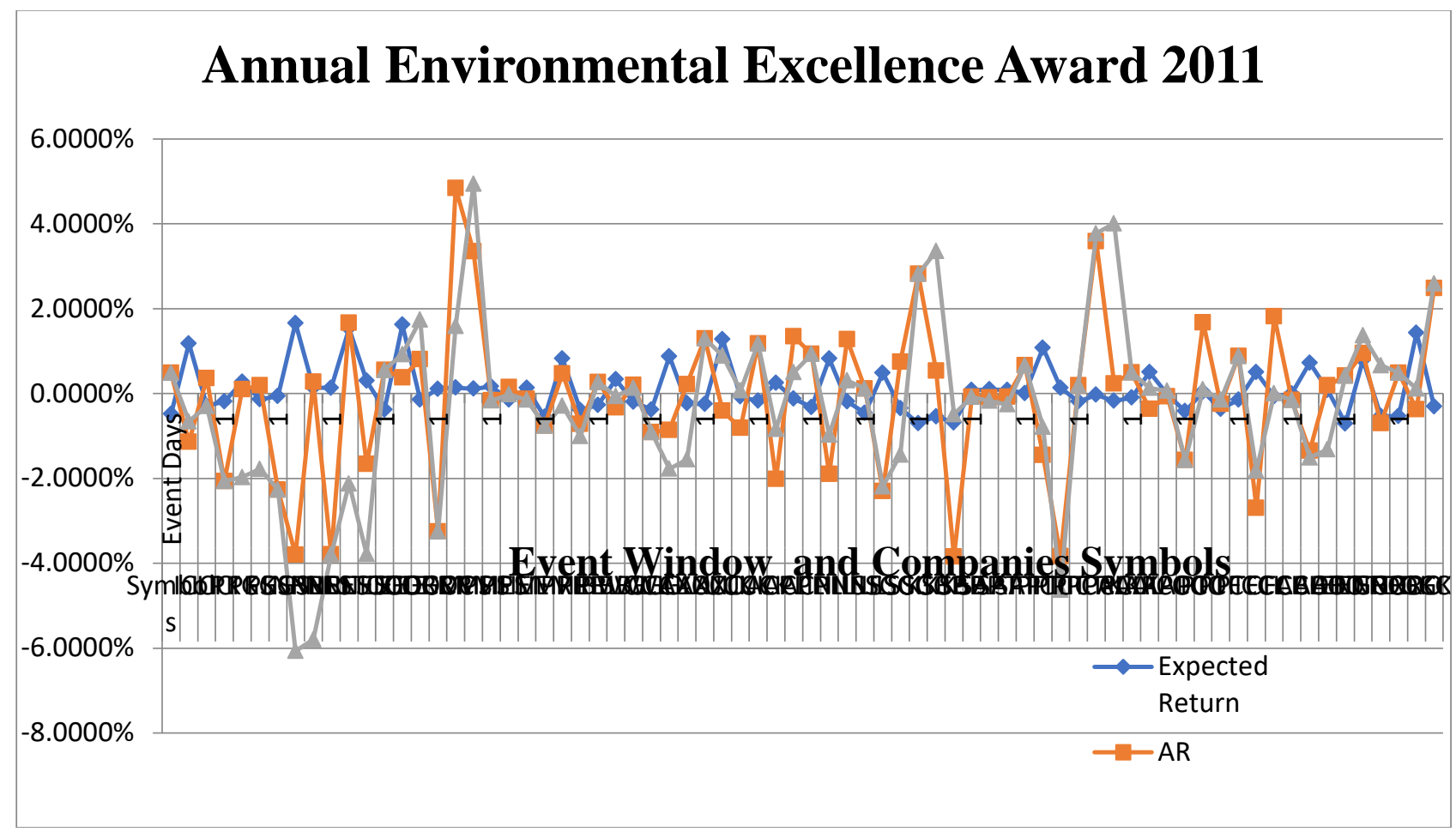

The above chart depicts the expected return, abnormal return and cumulative abnormal return of the events firms around the event window i.e. -1 and 1 days for year 2011. It shows that mostly companies have insignificant impact of CSR Award announcement on the share prices. Out of 63 companies who have wins CSR awards in the year 2011, only two companies have significant impact which includes RMPL and PCAL. RMPL has significant impact on the day of announcements $(4.82 \%)$ only, before $(-3.25 \%)$ and after $(3.34 \%)$ the announcements has insignificant impact. PCAL has significant impact on the day of announcements $(3.58 \%)$, before $(0.19 \%)$ and after $(0.23 \%)$ the announcement has impact insignificant.

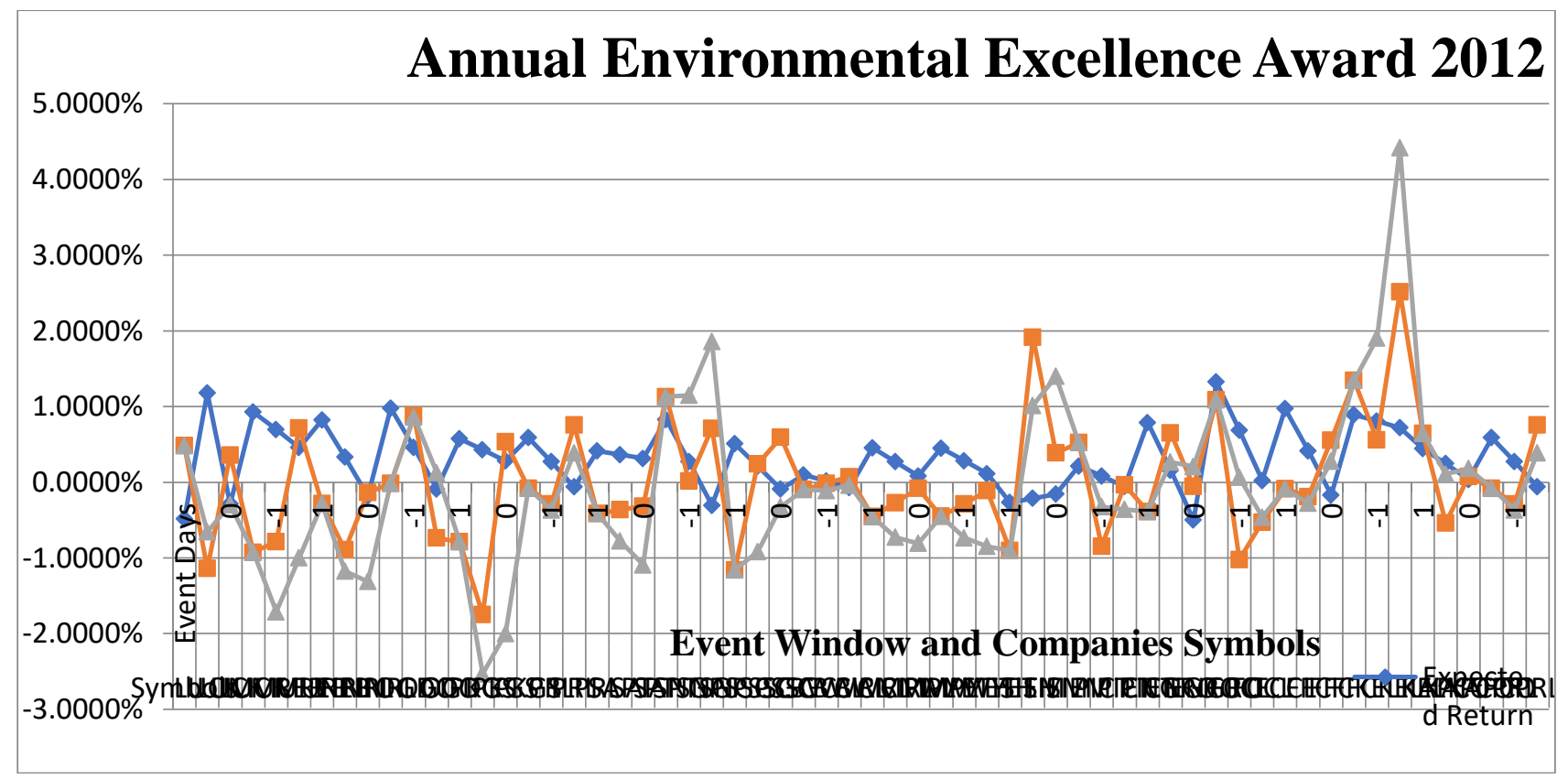

The above chart depicts the expected return, abnormal return and cumulative abnormal return of the events firms around the event window i.e. -1 and 1 day for year 2012. There are 73companies who wins CSR award that shows all companies have insignificant impact of CSR Award announcement on the share prices. 


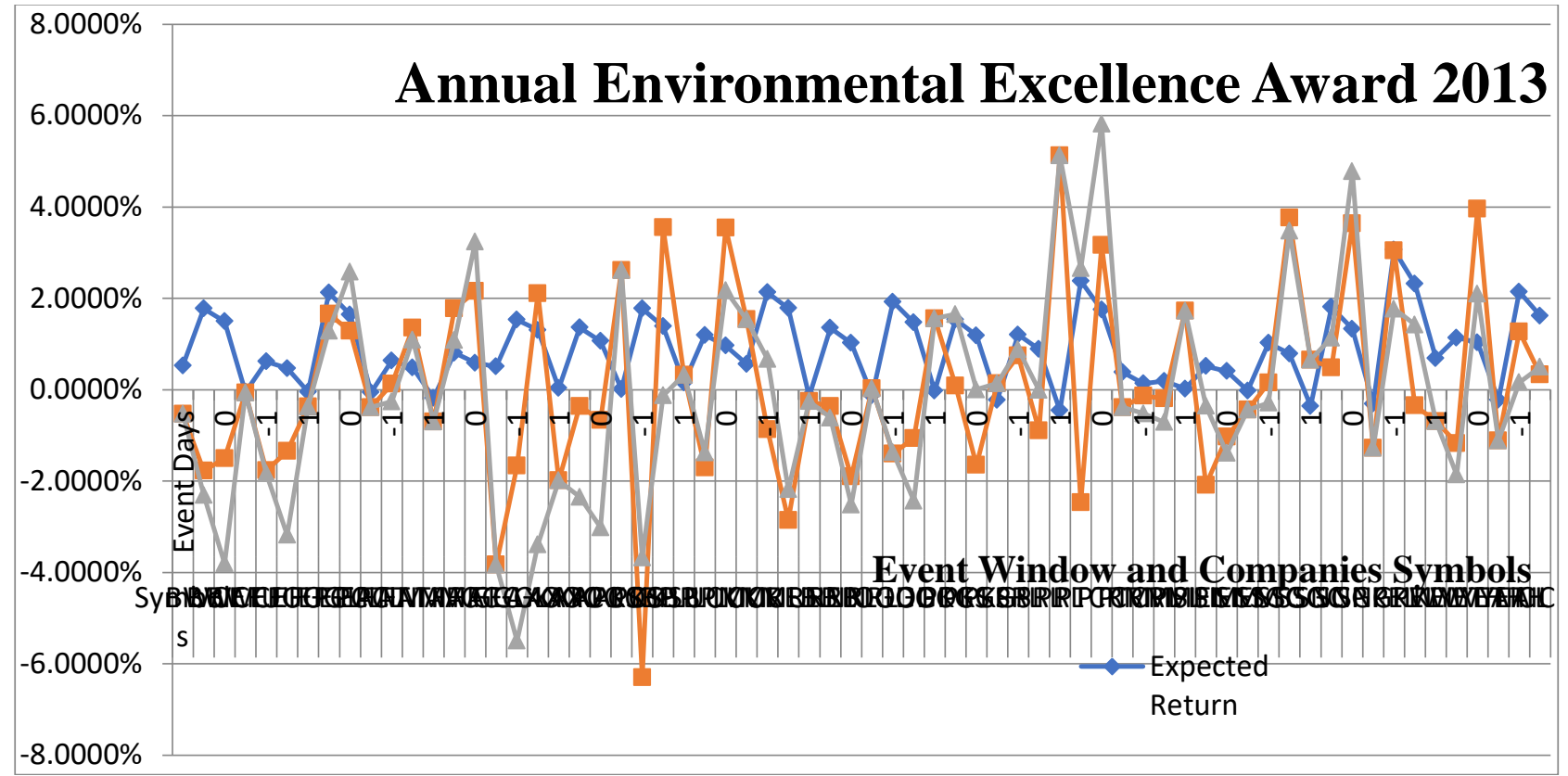

The above chart depicts the expected return, abnormal return and cumulative abnormal return of the events firms around the event window i.e. -1 and 1 day for year 2013. It shows that mostly companies have insignificant impact of CSR Award announcement on the share prices. Out of 64 companies who have wins CSR awards in the year 2013, only five companies have significant impact which includes FFC, LUCK, PKGS, PTC and SSGC. FFC has significant impact on the day of announcements $(1.77 \%)$ and after $(2.15 \%)$ the announcements but has insignificant impact before the announcements (-0.69\%). LUCK has significant impact after the announcements (3.54\%), has insignificant impact on the announcement and after the announcements. PKGS has significant impact on the day of announcement $(0.09 \%)$, has insignificant before and after the announcement. PTC has significant before the announcements (5.12\%). SSGS has significant impact after the announcements (3.76\%), has insignificant before and on the announcement's day.

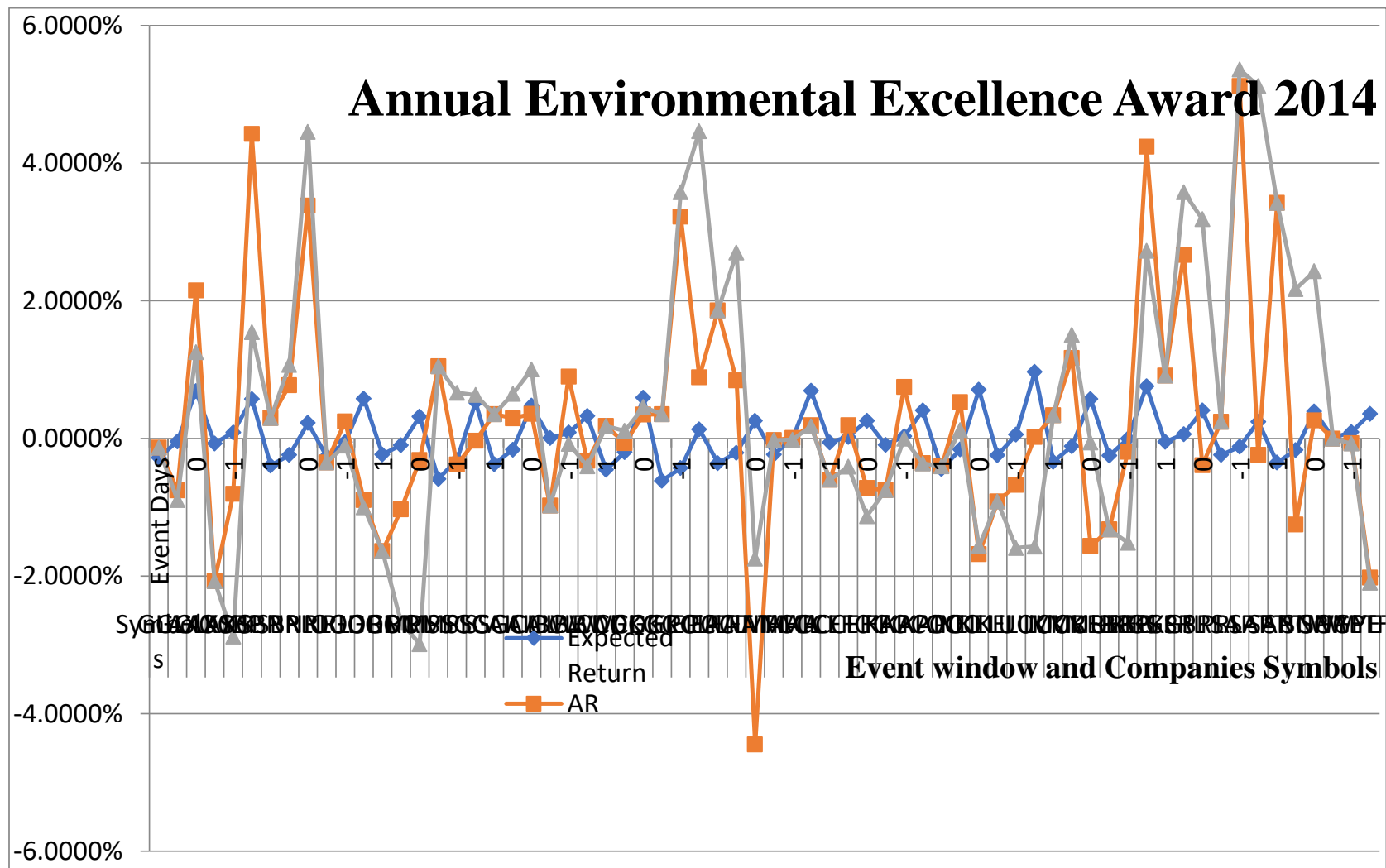


The above chart depicts the expected return, abnormal return and cumulative abnormal return of the events firms around the event window i.e. -1 and 1 day for year 2014. It shows that mostly companies have insignificant impact of CSR Award announcement on the share prices. Out of 64 companies who have wins CSR awards in the year 2014, only two companies have significant impact which includes KSBP and NRL. KSBP has significant impact after the day of announcements (4.42\%), has insignificant impact before the announcements $(-2.07 \%)$ and on the day of announcements (-0.8\%). NRL has significant impact after the announcements (3.83\%), has insignificant impact on the announcement $(0.77 \%)$ and before the announcements $(0.29 \%)$.

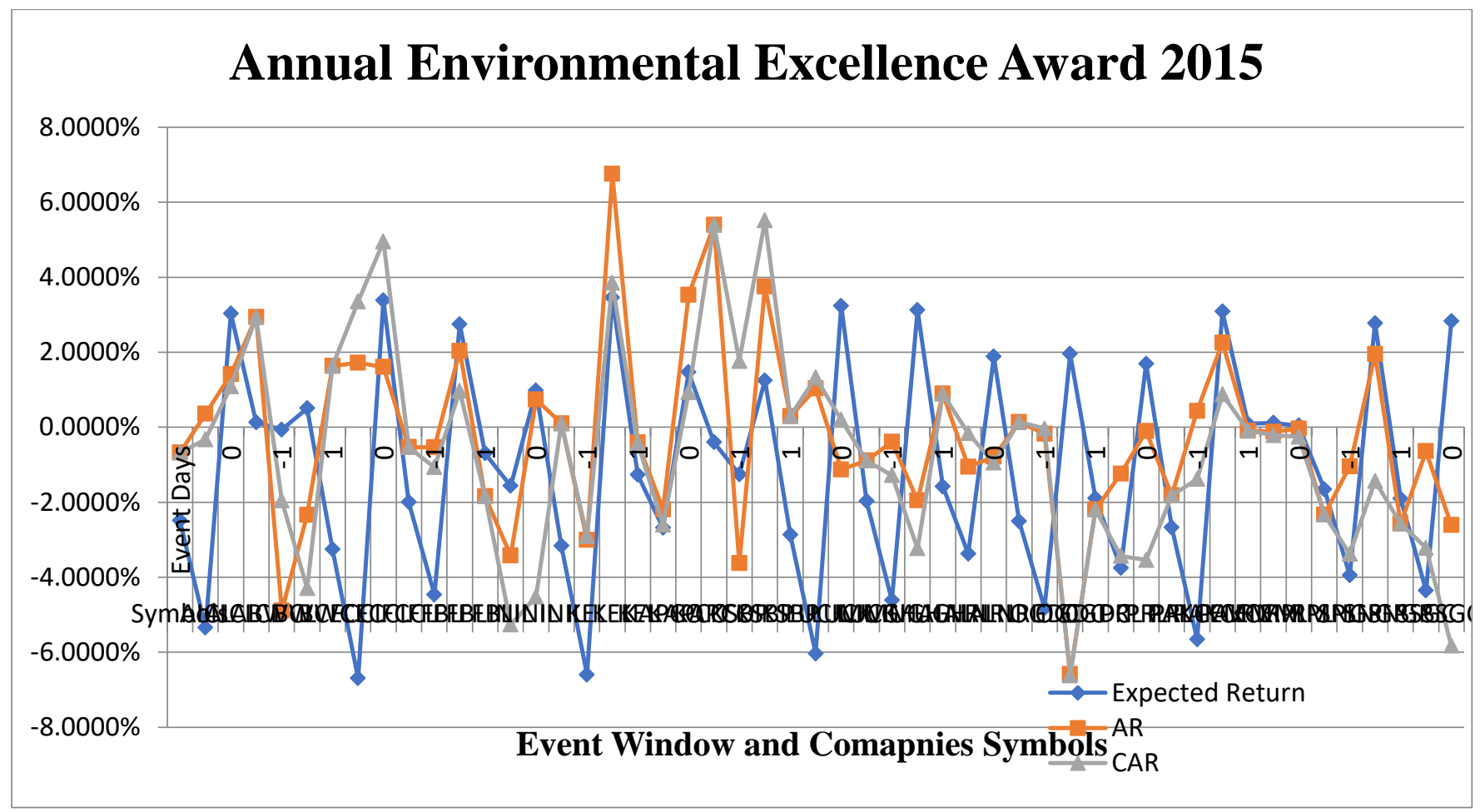

The above chart depicts the expected return, abnormal return and cumulative abnormal return of the events firms around the event window i.e. -1 and 1 day for year 2015. It shows that mostly companies have insignificant impact of CSR Award announcement on the share prices. Out of 59 companies who have wins CSR awards in the year 2015, only three companies have significant impact which includes KEL and KAPCO and KSBP has significant impact after the day of announcements (4.42\%), has insignificant impact before the announcements ($2.07 \%)$ and on the day of announcements $(-0.8 \%)$. NRL has significant impact after the announcements $(3.83 \%)$, has insignificant impact on the announcement $(0.77 \%)$ and before the announcements $(0.29 \%)$.

\subsection{Results of CSR Business Excellence Award}

In this section result about CSR Business Excellence Award has been discussed for the year 2013 to 2015 . We have only presented here chart which shows results about expected return, abnormal return and cumulative abnormal return. Tables about values are not presented here due to large data. 


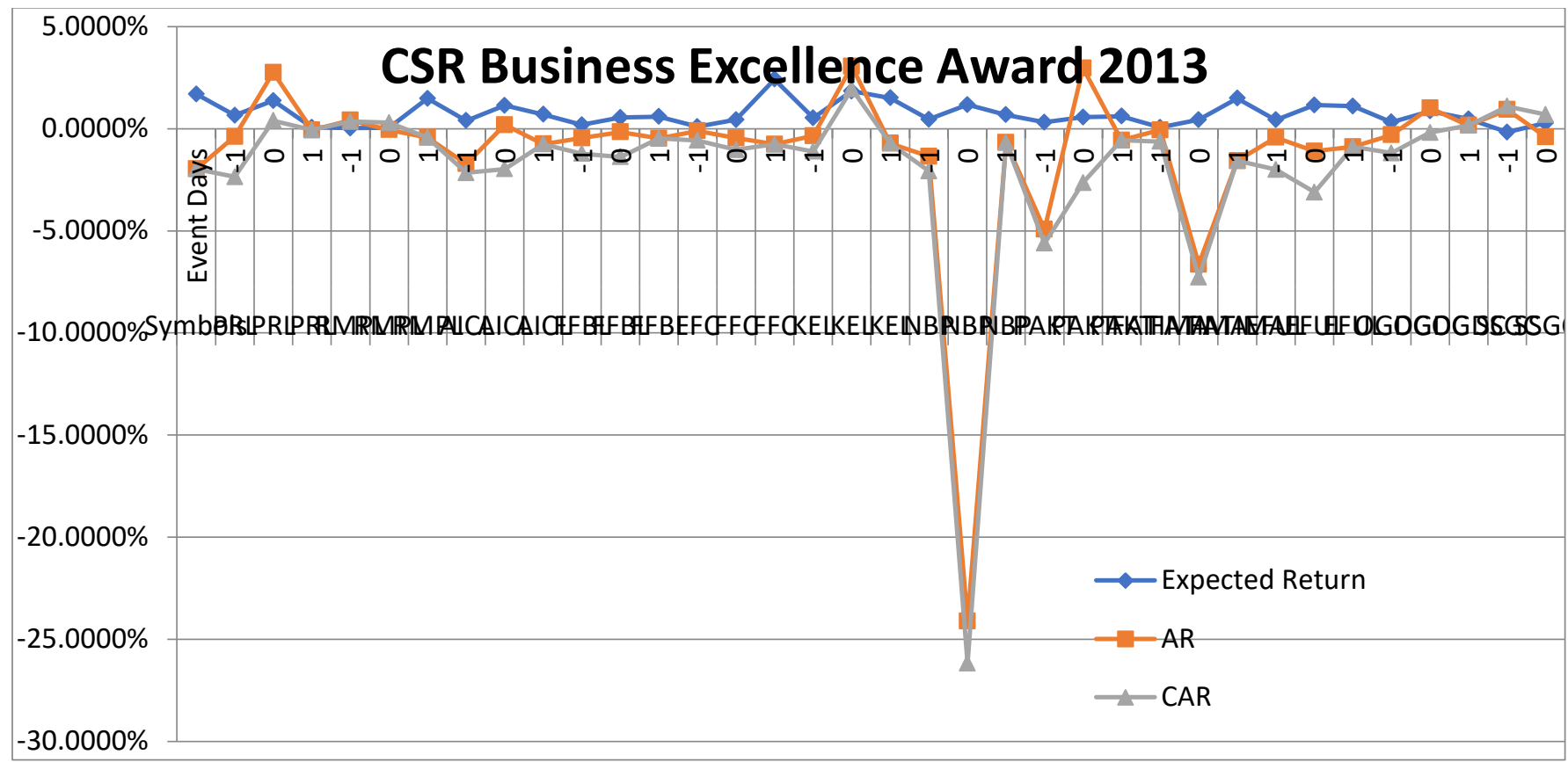

The above chart depicts the expected return, abnormal return and cumulative abnormal return of the events firms around the event window i.e. -1 and 1 day for year 2013. It shows that mostly companies have insignificant impact of CSR Award announcement on the share prices. Out of 40 companies who have wins CSR awards in the year 2013, only two companies have significant impact which includes FATIMA and NBP. NBP has significant impact after the announcements (-24.11\%), has insignificant impact before the announcements $(-0.71 \%)$ and on the announcements $(-1.35 \%)$.

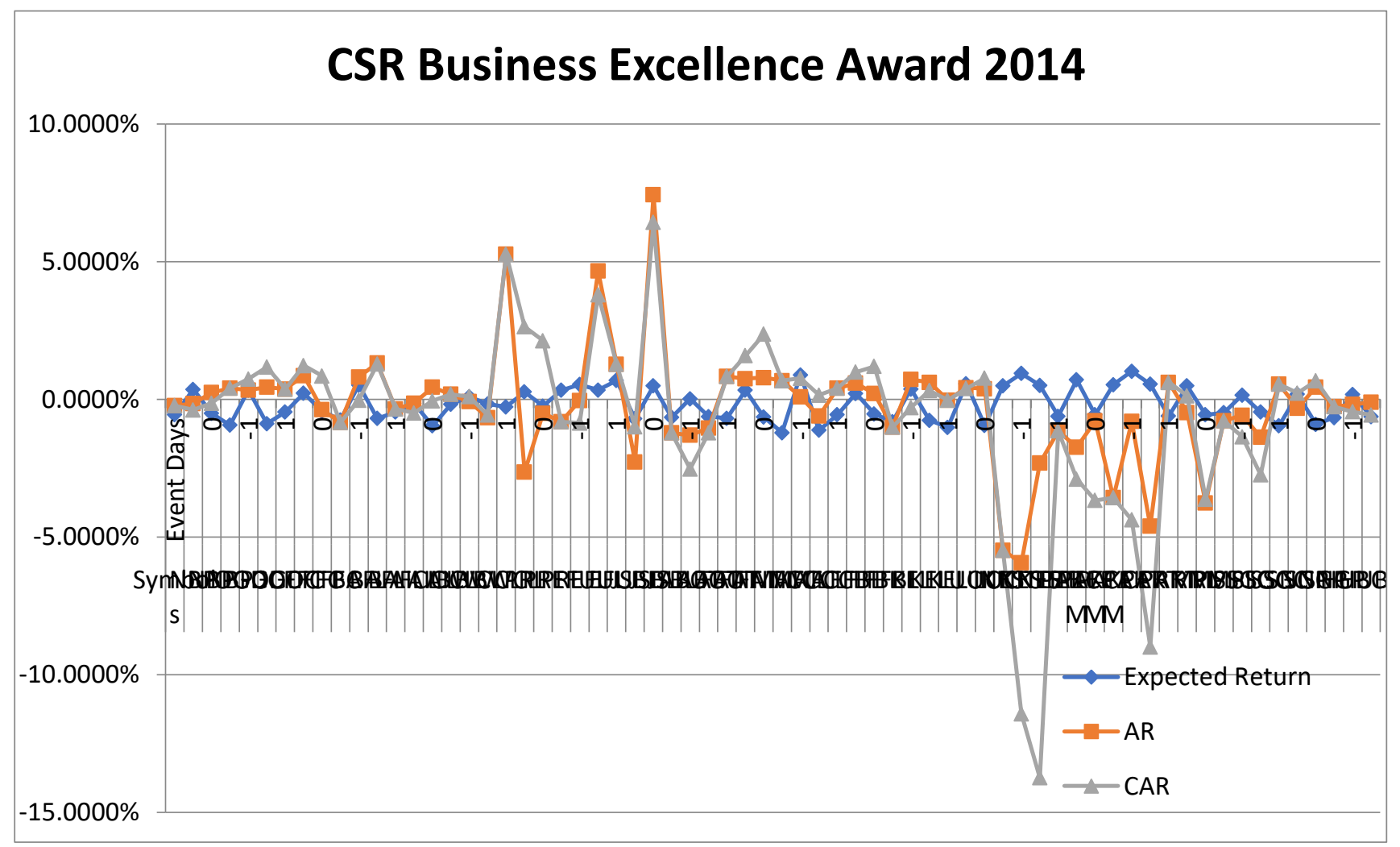

The above chart depicts the expected return, abnormal return and cumulative abnormal return of the events firms around the event window i.e. -1 and 1 day for year 2014. It shows that mostly companies have insignificant impact of CSR Award announcement on the share prices. Out of 41 companies who have wins CSR awards in the 
year 2014, only four companies have significant impact which includes PRL, EFU and JSBL. PRL has significant impact before the announcements (5.27\%), has insignificant impact on the announcement's day $(-2.64 \%)$ and after the announcements (-0.5\%). EFUL has significant impact after the announcement's day (4.65\%), has insignificant impact before the announcements $(-0.81 \%)$ and on the announcement's day $(-0.04 \%)$. JSBL has significant impact after the announcement's day (7.42\%), has insignificant impact before the announcements $(1.27 \%)$ and on the announcements day $(-2.27 \%)$.

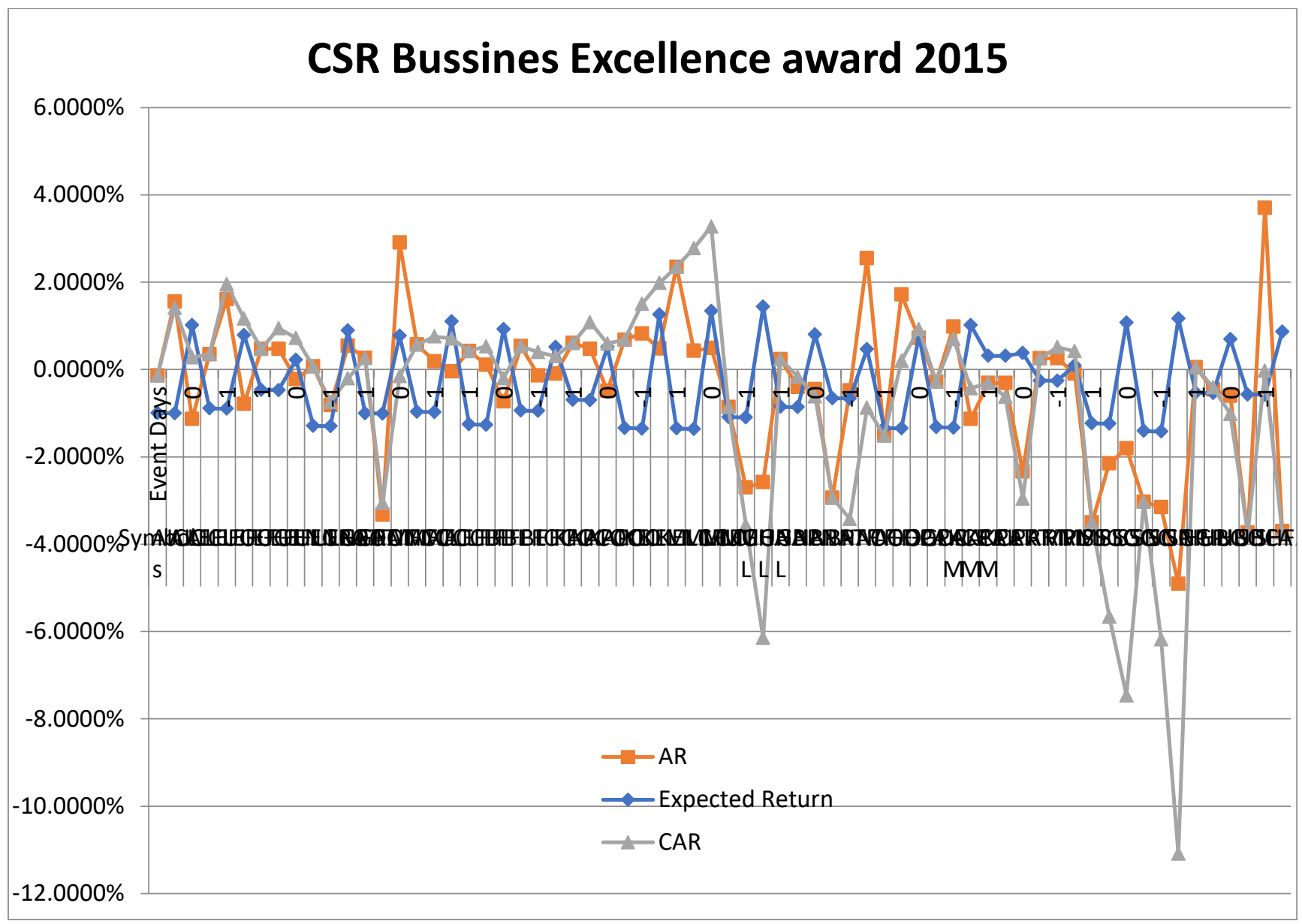

The above chart depicts the expected return, abnormal return and cumulative abnormal return of the events firms around the event window i.e. -1 and 1 day for year 2015. It shows that mostly companies have insignificant impact of CSR Award announcement on the share prices. Out of 48 companies who have wins CSR awards in the year 2015, only two companies have significant impact which includes FATIMA and SNGP. FATIMA has insignificant impact before the announcements $(0.26 \%)$, has significant impact on the announcement's day ($3.32 \%)$ and after the announcements $(2.90 \%)$. SNGP has significant impact after the announcement's day ($4.09 \%)$, has insignificant impact before the announcements (-3.03\%) and on the announcement's day (-3.15\%).

\section{Conclusion}

The basic objective of this study was to investigate the empirical relationship between CSR awards announcements and stock return of firms listed on the Pakistan Stock Exchange. To investigate the impact on the stock market return of firms an event study methodology has been conducted on the respective sample of CSR awards announcements. Normal return has been calculated over the period of estimation window of 120 days, then abnormal return has been calculated and then cumulative abnormal return has been calculated over the period of three days event window $[-1,0,1]$. The results of the event study describe that on the announcements of some awards market quickly reflects the new information and on the announcements of some other awards market respond few days later to absorb information. 
We found that there are some firms whose abnormal returns are positively significant with announcements of CSR awards and some firms have negatively significant impact of CSR awards announcements. Overall there is insignificant impact of CSR awards announcements on the stock prices which is measured by the abnormal return. Many firms have positive impact on the announcements of CSR awards and other firms has negative effect on the announcements of CSR awards but little effect which is insignificant.

This study contributes to the literature of CSR in terms of its impact on stock prices. This study has some implications for policy makers and practitioners. The business case for CSR must be established for the promotion of CSR. Investors, stakeholders and financial analysts must be provided awareness about the importance of CSR. Unless, positive performance of companies in terms of social responsibility is not given due consideration by the stock market, no way companies be attracted towards CSR initiatives. Getting CSR awards may add to the corporate reputation and soft image of the company but unless this award is reflected in the stock prices, companies will pay little attention to this. This study is limited to the reaction of Pakistani stock market towards CSR awards of National Forum for Environment and Health. Future studies may be conducted in other countries and may consider other award schemes for more evidence.

\section{References}

Arya, B., \& Zhang, G. (2009). Institutional reforms and investor reactions to CSR announcements: Evidence from an emerging economy. Journal of management studies, 46(7), 1089-1112.

Baird, P. L., Geylani, P. C., \& Roberts, J. A. (2012). Corporate social and financial performance re-examined: Industry effects in a linear mixed model analysis. Journal of Business Ethics, 109(3), 367-388.

Barone, M. J., Miyazaki, A. D., \& Taylor, K. A. (2000). The influence of cause-related marketing on consumer choice: does one good turn deserve another? Journal of the academy of Marketing Science, 28(2), 248-262.

Bass, B. M., \& Steidlmeier, P. (1999). Ethics, character, and authentic transformational leadership behavior. The leadership quarterly, 10(2), 181-217.

Basu, K., \& Palazzo, G. (2008). Corporate social responsibility: A process model of sensemaking. Academy of management review, 33(1), 122-136.

Berens, G., Van Riel, C. B., \& Van Bruggen, G. H. (2005). Corporate associations and consumer product responses: The moderating role of corporate brand dominance. Journal of marketing, 69(3), 35-48.

Brammer, S., Brooks, C., \& Pavelin, S. (2009). The stock performance of America's 100 best corporate citizens. The Quarterly Review of Economics and Finance, 49(3), 1065-1080.

Campbell, J. L. (2007). Why would corporations behave in socially responsible ways? An institutional theory of corporate social responsibility. Academy of management review, 32(3), 946-967.

Caruana, R., \& Crane, A. (2008). Constructing consumer responsibility: Exploring the role of corporate communications. Organization studies, 29(12), 1495-1519.

Choi, J., \& Wang, H. (2009). Stakeholder relations and the persistence of corporate financial performance. Strategic Management Journal, 30(8), 895-907.

Chollet, P., \& Cellier, A. (2011). The impact of corporate social responsibility rating announcements on European stock prices. Paper presented at the International conference of the French finance association (AFFI).

Crouch, C. (2006). Modelling the firm in its market and organizational environment: Methodologies for studying corporate social responsibility. Organization studies, 27(10), 1533-1551.

Gupta, A. (2006). Impact of earnings announcements on stock prices: some empirical evidences from India. The ICFAI Journal of Applied Finance, 12(3), 5-13.

Kong, S., \& Taghavi, M. (2006). The effect of annual earnings announcements on the Chinese Stock Markets. International Advances in Economic Research, 12(3), 318-326.

Kothari, S. P., \& Warner, J. B. (2007). Econometrics of event studies. In Handbook of empirical corporate finance (pp. 3-36): Elsevier.

MacKinlay, A. C. (1997). Event studies in economics and finance. Journal of economic literature, 35(1), 1339.

Maina, J. (2009). An empirical investigation of stock returns reaction around earnings announcements for quoted companies at NSE. MBA project, University of Nairobi.

Makni, R., Francoeur, C., \& Bellavance, F. (2009). Causality between corporate social performance and 
financial performance: Evidence from Canadian firms. Journal of Business Ethics, 89(3), 409.

McWilliams, A., \& Siegel, D. (1997). Event studies in management research: Theoretical and empirical issues. Academy of Management journal, 40(3), 626-657.

McWilliams, A., Siegel, D., \& Teoh, S. H. (1999). Issues in the use of the event study methodology: A critical analysis of corporate social responsibility studies. Organizational Research Methods, 2(4), 340-365.

McWilliams, A., Siegel, D. S., \& Wright, P. M. (2006). Corporate social responsibility: Strategic implications. Journal of management studies, 43(1), 1-18.

Moskowitz, M. (1972). Choosing socially responsible stocks. Business and Society Review, 1(1), 71-75.

Orlitzky, M., Schmidt, F. L., \& Rynes, S. L. (2003). Corporate social and financial performance: A metaanalysis. Organization studies, 24(3), 403-441.

Patell, J. M., \& Wolfson, M. A. (1984). The intraday speed of adjustment of stock prices to earnings and dividend announcements. Journal of financial economics, 13(2), 223-252.

Scalet, S., \& Kelly, T. F. (2010). CSR rating agencies: what is their global impact? Journal of Business Ethics, 94(1), 69-88.

Sen, S., Bhattacharya, C. B., \& Korschun, D. (2006). The role of corporate social responsibility in strengthening multiple stakeholder relationships: A field experiment. Journal of the academy of Marketing Science, 34(2), 158-166.

Simmons, C. J., \& Becker-Olsen, K. L. (2006). Achieving marketing objectives through social sponsorships. Journal of marketing, 70(4), 154-169.

Ullmann, A. A. (1985). Data in search of a theory: A critical examination of the relationships among social performance, social disclosure, and economic performance of US firms. Academy of management review, 10(3), 540-557.

Vance, S. C. (1975). Are socially responsible corporations good investment risks. Management review, 64(8), 19-24.

Varadarajan, P. R., \& Menon, A. (1988). Cause-related marketing: A coalignment of marketing strategy and corporate philanthropy. Journal of marketing, 52(3), 58-74.

Weber, M. (2008). The business case for corporate social responsibility: A company-level measurement approach for CSR. European Management Journal, 26(4), 247-261.

Zanotti, G. (2012). Demutualization and the globalization of stock markets. Handbook of Research on Stock Market Globalization, 163. 
